\title{
ASPIRASI LIBERALISME, NASIONALISME DAN SOSIALISME DALAM MENGINTERPRETASI REVOLUSI 1848 DI JERMAN
}

\author{
Low Choo Chin
}

\begin{abstract}
This article examines the origins of the 1848 Revolution using Germany as a case study. It aims to analyze the existing interpretations explaining the outbreak of the March Revolution: liberalism, nationalism, and socialism. The call to reform the political order, the aspiration to unify the various German states, and the desire to rectify the growing socioeconomic discontent, explained the factors of the revolution. This article argues that the events of 1848 were the "revolution of the masses" rather than a bourgeois revolution. The masses, comprising the artisan, peasants, and the working class, were only ready to identify themselves with the ideological struggles of the bourgeois as long as their socioeconomic ills were resolved. While the bourgeoisie provided intellectual leadership, the people were the main revolutionary forces. The revolution gained momentum with the active participation of the masses and the premature revolution collapsed when the masses failed to come to the support of the bourgeoisie in anti-revolution campaigns launched by the monarchy. This article suggests that it was oppression rather than ideology, which gave decisive impetus to the 1848 movement.
\end{abstract}

\section{Pengenalan}

Revolusi 1848 merupakan suatu pergerakan mencabar susunan politik dan sosial yang melanda seluruh benua Eropah. Seperti negara-negara 
Eropah yang lain, Jerman berkongsi pengalaman revolusi yang serupa. Satu persamaan antara semua revolusi 1848 di Eropah adalah pergerakan tersebut merupakan "pergerakan perlembagaan." Terdapat tuntutan perlembagaan yang hampir sama oleh kelas pertengahan untuk satu sistem baru berdasarkan satu perlembagaan bertulis yang akan memberi lebih banyak hak sivil dan politik. Selain itu, gerakan revolusi di seluruh Eropah dipengaruhi oleh ideologi nasionalisme. Di Jerman, pergerakan nasionalisme menuntut pembentukan sebuah parlimen Jerman pada peringkat kebangsaan dan penyatuan negerinegeri Jerman dalam satu negara bangsa. Satu lagi ciri persamaan dalam revolusi 1848 adalah kewujudan krisis sosioekonomi di benua Eropah yang diakibatkan oleh pertambahan penduduk, perindustrian dan kemiskinan. Rusuhan tempatan akibat kebuluran merebak luas di seluruh Eropah dan pada masa sama berlaku imigrasi besar-besaran.

Sejarawan masih belum mencapai kata sepakat mengenai faktor penggerak utama di sebalik revolusi 1848 di Jerman sama ada seruan liberalisme, cita-cita nasionalisme dan keinginan mengatasi masalah sosioekonomi. Dalam menjelaskan faktor revolusi yang lebih dominan, adalah perlu menentukan sama ada gerakan itu suatu gerakan kelas bawahan atau kelas pertengahan. Golongan kelas bawahan dilihat memainkan peranan yang lebih dominan berbanding kelas pertengahan. Oleh itu, faktor sosioekonomi yang menggerakkan penglibatan kelas bawahan dilihat sebagai punca revolusi. Selain mengenal pasti faktor revolusi, terdapat juga cabaran-cabaran yang dihadapi oleh gerakan revolusi dalam merealisasikan matlamat pembaharuan perlembagaan dan penyatuan Jerman. Kedua-dua matlamat tersebut tidak berjaya dicapai apabila Revolusi Mac di Jerman, sepertimana revolusi 1848 di negara Eropah lain berjaya ditumpaskan oleh kerajaan monarki pada Julai 1849. Walaupun jangka masa gerakan revolusi hanya satu setengah tahun, kepentingan revolusi dalam sejarah pendemokrasian dan nasionalisme Jerman tidak boleh diabaikan.

\section{Definisi Revolusi 1848}

Kesedaran politik rakyat meningkat secara mendadak dan pergerakan rakyat menjadi popular berikutan kombinasi tuntutan untuk demokrasi, pergerakan nasionalis dan konflik sosioekonomi. ${ }^{1}$ Dalam menjelaskan faktor revolusi yang lebih dominan, adalah perlu menentukan sama ada gerakan itu suatu gerakan politik, sosioekonomi atau ideologi. Umumnya, terdapat empat aliran pemikiran mengenai revolusi Jerman 1848 iaitu konservatif, liberal, radikal dan sosialis. Bagi golongan konservatif, mereka berpuas hati dengan keadaan di Jerman sebelum tercetusnya revolusi 18 Mac 1848. Golongan konservatif ini 
tidak berpendapat terdapatnya justifikasi untuk mengubah keadaan semasa ataupun menganjurkan pemberontakan. Mereka menyalahkan golongan intelektual yang mengambil kesempatan atas krisis ekonomi untuk memperdaya rakyat yang selama ini setia kepada pemerintah tempatan. Bagi golongan liberal pula, terdapat kekurangan pada sistem sedia ada dan masanya telah sampai untuk suatu gerakan reformasi. Golongan ini cuba mencari satu kompromi antara mengekalkan autoriti lama dan memenuhi tuntutan revolusi. Kegagalan revolusi menunjukkan bahawa golongan monarki tidak akan berkompromi untuk memberi konsesi pembaharuan liberal. Namun begitu, kegagalan revolusi tidaklah bererti bahawa keperluan untuk pembaharuan liberal tidak wujud tetapi keperluan tersebut ditundakan. ${ }^{2}$

Aliran pemikiran yang ketiga iaitu radikalisme. Golongan radikal berpendapat revolusi 1848 adalah percubaan sah oleh rakyat untuk menghapuskan susun lapis masyarakat yang menindas dan menggantikannya dengan sebuah republik yang demokratik. Mereka ingin melihat semua rakyat Jerman mengambil bahagian dalam menentukan hala tuju kerajaan. Golongan ini mempersalahkan pihak borjuis atas kegagalan revolusi. Pihak borjuis yang telah menerajui kepimpinan awal revolusi menentang autoriti lama telah membuat janji kosong untuk pembaharuan dan menyebelahi raja dalam gerakan anti-revolusi. Kumpulan sosialis sungguhpun bersetuju dengan analisis golongan radikal, berpendapat pandangan radikalisme adalah terhad. Bagi sosialis, revolusi yang sebenar mestilah menjangkaui satu kekacauan politik dan mestilah merupakan satu tindak balas kepada masalah sosial yang diakibatkan oleh perindustrian. Revolusi bukan sahaja bertujuan menggulingkan sistem politik lama tetapi juga memperbaharui sistem pembahagian ekonomi yang sedia wujud. ${ }^{3}$

Menurut Rudolph Stadelmann, teori yang menerangkan asal usul revolusi sebagai suatu pergerakan menuntut perubahan dalam sistem pentadbiran lama adalah terlalu "simplistic." Sekiranya revolusi disebabkan oleh penentangan rakyat terhadap pemerintahan autokratik kerajaan dan sekatan kebebasan rakyat, mengapa revolusi tidak tercetus pada lebih awal? Fenomena ketidakpuasan rakyat telahpun wujud sejak awal lagi sebelum 1848. Oleh itu, kelemahan sistem kerajaan tidak boleh dipersalahkan sebagai punca utama revolusi. Stadelmann juga mengkritik teori revolusi yang melihat faktor ekonomi atau kemiskinan sebagai faktor penggerak revolusi. Walaupun teori kedua ini mengambil kira faktor kemunculan kelas sosial baru dan melihat revolusi sebagai pergerakan massa, faktor ekonomi semata-mata tidak memadai untuk pencetusan revolusi. Menurut Stadelmann, teori ini juga mempunyai kelemahan kerana tidak mengambil kira faktor psikologi. Pengaruh ideologi, menurut beliau, menghasilkan impak yang lebih tinggi untuk 
sebarang tindakan berbanding dengan ketidakpuasan terhadap keadaan semasa. ${ }^{4}$

Berdasarkan faktor psikologi ini, kesedaran penderitaan, perasaan untuk keperluan pembaharuan bermula dengan penyebaran idea. Idea subversif atau radikal menjadi ketara apabila muncul kelas baru yang mencabar pemerintahan lama.

The path to the revolution is formed not by the strongest arms not by the most extreme poverty, but rather among subtilized thought and philosophical programs...The ever-present economic and social needs seem then to be no more than the humus in which the seeds of ideas can develop with a prospect of success among the masses... ${ }^{5}$

Sejarawan lain turut mengkritik pendekatan politik dalam menjelaskan revolusi 1848 . Theodore S. Hamerow menegaskan bahawa peristiwa 1848 berakar umbi pada keadaan material misalnya kemerosotan taraf hidup terutamanya golongan artisan dan krisis ekonomi. Tumpuan khusus kepada perjuangan politik seperti aspek perlembagaan dan penyatuan negara bangsa Jerman oleh golongan kelas pertengahan mengetepikan pendekatan sosioekonomi yang menjadikan 'rakyat jelata matang untuk revolusi. ${ }^{\prime 6}$ Revolusi Jerman memperlihatkan perjuangan dari dua aspek iaitu politik dan sosial. Dari aspek politik, terdapat tuntutan pembaharuan liberal dan penglibatan rakyat dalam kerajaan. Tuntutan politik ini berserta dengan tuntutan untuk pembaharuan sistem sosial Jerman. Dalam situasi ini, golongan profesional dan kelas pertengahan bekerjasama dengan golongan petani dan artisan untuk mencapai kedua-dua objektif tersebut. Kebanyakan penyelidik Jerman berpendapat situasi sosial adalah lebih menonjol kerana revolusi hanya bermula dengan adanya kehadiran golongan petani, artisan dan pekerja. Golongan bawahan ini merupakan pejuang utama di benteng-benteng pertahanan menentang tentera diraja. ${ }^{7}$

Jika golongan bawahan merupakan pusat tenaga revolusi, maka wajarlah faktor sosioekonomi dikatakan memainkan peranan yang lebih berpengaruh. Dalam menjawab persoalan sama ada faktor politik atau sosial yang lebih menonjol dalam kes di Jerman, adalah perlu untuk melihat peranan golongan bawahan dan golongan kelas pertengahan (intelektual). Adakah revolusi Jerman 1848 suatu revolusi kelas pertengahan atau revolusi kelas bawahan?

\section{Revolusi Artisan Atau Revolusi Intelektual}

Revolusi 1848 dilabelkan sebagai revolusi dari bawah yang digerakkan oleh kelas bawahan. Jika diteliti komposisi keahlian yang terlibat 
peringkat awal revolusi, sebenarnya dua pertiga yang terlibat adalah golongan bawahan masyarakat yang dipengaruhi secara langsung oleh krisis sosioekonomi seperti petani, buruh, pedagang, pekerja kilang dan pekerja pembinaan. Ini jelas terbukti dengan berlakunya rusuhan di kilang dan tapak pembinaan jalan. ${ }^{8}$ Antara pelbagai lapisan golongan bawahan, artisan adalah kumpulan pejuang yang bersifat lebih radikal disebabkan kedudukan sosioekonomi yang tergugat hasil daripada perkembangan kilang, perdagangan bebas dan persaingan dalam kalangan mereka. Artisan mengalami kepayahan yang lebih berbanding pekerja kilang dan keperitan itu menyebabkan mereka terlibat secara aktif. Maka tidak hairanlah sekirannya kumpulan ini yang mendemontrasi, merusuh, menggugat pemilik kilang, memusnahkan kilang. Malahan golongan artisan yang mengorganisasikan revolusi dan lebih menyokong revolusi dan bukannya kelas pertengahan. Dengan erti kata lain, mereka adalah pembekal angkatan revolusi. ${ }^{9}$

Peranan golongan intektual adalah lebih kepada sumbangan kepimpinan. Revolusi 1848 tercetus dalam kalangan dua golongan sosial iaitu kelas bawahan (majoritinya artisan) dan kelas pertengahan (majoritinya intelektual). Kedua-dua golongan ini bekerjasama dengan kumpulan artisan membekalkan tenaga askar dan intelektual memimpin perjuangan itu. Kepimpinan golongan intelektual terbukti pada peringkat kebangsaan (seperti parlimen) dan peringkat negeri. ${ }^{10}$ Jika kumpulan artisan merusuh kerana faktor kemiskinan, kumpulan intelektual pula merusuh kerana kekurangan status. Ketidakpuasan golongan berpendidikan tinggi ini berpunca daripada ketiadaan mobiliti sosial dalam masyarakat Jerman. Sistem pendidikan Jerman pula telah menghasilkan jumlah siswazah yang berlebihan menjauhi pasaran kerja. Ini menjelaskan sebab penglibatan tenaga buruh berpendidikan dalam revolusi. Daripada jumlah 586 ahli parlimen Franfurt, 479 merupakan birokrat, profesor, pegawai kehakiman, peguam, pemilik tanah dan peniaga. Daripada penglibatan intektual dalam peringkat kebangsaan, revolusi 1848 digambarkan sebagai "the revolution of the intellectuals."11

Namun begitu, revolusi tidak mungkin mencapai kuasa yang dinamik tanpa penglibatan kelas bawahan. Tanpa mereka, pergerakan revolusi akan kekal di bawah pemimpin tanpa tentera atau penyokong. Bersama-sama dengan kelas pekerja, petani dan artisan membentuk kebanyakan tenaga pejuang di benteng-benteng pertahanan. ${ }^{12}$ Kebangkitan golongan pekerja kilang dan artisan dalam revolusi dikaitkan dengan persoalan sosial iaitu kesusahan hidup mereka. Persoalan sosial ini disebabkan oleh isu-isu yang kompleks seperti keadaan kerja di kilang, masalah perumahan, pembubaran kumpulan sekerja, dan pengenalan ekonomi kapitalis berdasarkan persaingan. Namun begitu, isu utama adalah kemiskinan (pauperization) dalam 
kalangan susun lapis sosial yang rendah. Kemiskinan yang dialami pada 1840-an adalah amat berbeza dengan yang dialami sebelum ini kerana krisis kemiskinan ini adalah satu fenomena menyeluruh yang melanda penduduk secara kolektif dan berterusan. Pertambahan populasi terutamanya di luar bandar merupakan sebab utama kemiskinan. Buktinya ialah peningkatan penduduk sebanyak 56 peratus dalam jangka masa 1816-46 daripada 10.3 juta kepada 15.9 juta di kawasan luar bandar Prussia. ${ }^{13}$

Kesannya nyata apabila peningkatan penduduk tidak diimbangi dengan bekalan makanan dan peningkatan harga barangan semakin serius. Peningkatan dalam tenaga buruh juga tidak dapat diimbangi dengan permintaan untuk produk pembuatan apabila ekonomi Eropah menjadi lembap. Dalam tempoh masa yang sama di Prusia, bilangan artisan meningkat 70 peratus dan perantis artisan meningkat 156 peratus. Maka tidak hairan sekiranya taraf kehidupan rakyat semakin merosot. Bekalan makanan masih berkurangan akibat daripada bencana alam, hasil tuaian yang sedikit, epidemik lembu, dan penyakit tanaman. Pada 1846 misalnya, kegagalan tuaian menyebabkan harga makanan meningkat dua kali ganda dan diikuti dengan penyakit yang melanda tanaman kentang tanaman kentang telah mempengaruhi banyak wilayah yang bergantung pada tanaman ini. Peningkatan harga seterusnya diikuti oleh rusuhan-rusuhan makanan. Dalam jangka masa April sehingga Mei 1847, berlaku 158 rusuhan makanan.Selain itu, perarakan, serangan ke atas kedai-kedai dan sekatan jalan raya menjadi fenomena yang biasa. $^{14}$

Hamerov berpendapat rusuhan disebabkan oleh faktor kebuluran lebih daripada faktor ideologi. Kebuluran adalah realiti yang dihadapi oleh rakyat jelata dan faktor ini dilihat lebih berpotensi untuk memobilisasikan rakyat jelata. Orang ramai melancarkan rusuhanrusuhan secara berasingan untuk taraf hidup yang lebih terjamin. Rusuhan pekerja keretapi di Brandenburg menentang pengurangan gaji pada 1846, rusuhan pekerja kain di Saxony untuk menghapuskan mesin, pertempuran antara rakyat dan tentera di Leipzig pada 1845 dan kemudiannya di Bavaria dan Brunswick, Stuttgart dan Württemberg. Menjelang 1847, rusuhan dan pertempuran di antara orang ramai dengan tentera menjadi perkara biasa serta rusuhan-rusuhan kebuluran meletus hampir di setiap negeri Jerman. ${ }^{15}$

Krisis ini menonjolkan semua masalah yang telahpun melanda masyarakat Jerman sejak 1800 dan membawa kepada kerjasama antara proletariat (kelas pekerja) dengan borjuis (kelas pertengahan) untuk menggulingkan rejim lama. Ramai petani terpaksa berhijrah ke bandar, yang kemudiannya menjadi penggangur dan mewujudkan bekalan buruh yang berlebihan. Perlu diketahui bahawa krisis ini 
bukan sahaja menjejaskan penduduk luar bandar malahan penduduk bandar. Hamerov bersetuju bahawa golongan artisan yang paling serius dipengaruhi oleh krisis itu. Beribu-ribu artisan di bandar dihentikan kerja selepas 1845 apabila majikan mereka cuba mengelakkan kebankrapan. Kebanyakan buruh mahir terpaksa mencari kerja lain yang tidak sepadan dengan kemahiran mereka (dengan gaji yang lebih rendah). Sungguhpun pekerja kilang terpaksa berhadapan dengan masa kerja yang panjang dan gaji yang berkurangan, mereka masih mampu menghadapi krisis itu. Permintaan untuk pekerja kilang lebih stabil dan gajinya lebih tinggi daripada buruh tidak mahir. Tidak hairanlah jikalau artisan yang merupakan angkatan revolusi. Bagi golongan penduduk bandar yang lain, keadaan adalah amat membimbangkan dengan peningkatan golongan yang bergantung pada bantuan kerajaan, penurunan kadar isi rumah yang layak dicukai, peningkatan bilangan pengemis, kadar jenayah dan penghijrahan. ${ }^{16}$

Theodore S. Hamerov mengambarkan zaman krisis ekonomi pada 1840-an sebagai the hungry forties. Kemelesetan ini telah menyatukan pelbagai kumpulan sosioekonomi tanpa mengira perbezaan latar belakang untuk membentuk satu kuasa politik. Krisis ini mencapai kemuncaknya menjelang Revolusi Mac 1848. Penglibatan kelas bawahan sebenarnya memberikan kelebihan kepada perjuangan perlembagaan kelas pertengahan, yakni lebih sokongan dan tenaga manusia yang sedia menggunakan kekerasan untuk menggulingkan rejim lama. Krisis ekonomi menyediakan asas revolusi dengan menyediakan sokongan rakyat dan membolehkan kelas pertengahan mengambil arah yang lebih radikal. ${ }^{17}$

Di Eropah, golongan aristokrat kehilangan pengaruh politik dan revolusi meletakkan kelas pertengahan sebagai pemimpin yang mampu merealisasikan idea kerajaan berperlembagaan. Borjuis hanya boleh berjaya dengan wujudnya ketidakpuasan proletariat. Daripada 89 orang yang terbunuh dalam Revolusi Mac, 74 orang merupakan artisan. Revolusi bukannya semata-mata politik tetapi berasaskan situasi sosial. ${ }^{18}$

\section{Kegagalan Tuntutan Perlembagaan Sebelum 1848}

Sokongan kelas bawahan memberi momentum baru kepada perjuangan perlembagaan golongan borjuis yang selama ini tidak diiktiraf oleh raja. Nampaknya golongan liberal di parlimen-parlimen negeri bersedia untuk menerajui kepimpinan mencabar autoriti dan mentransfomasikan rusuhan berasingan kepada satu revolusi yang menyeluruh. Akhbar liberal mengkritik peraturan penapisan akhbar secara terbuka dan ahli parlimen negeri mengkritik pentadbiran Konfederasi Jerman. Di negeri Baden, bahagian selatan Jerman, pemimpin yang radikal berkumpul 
pada 12 September 1847 untuk mengesahkan program mereka. Kerajaan negeri Baden dituntut supaya memaktubkan perkara-perkara seperti kebebasan bersuara, akhbar dan perhimpunan, pengiktirafan parlimen Konfederasi sebagai badan tunggal yang mewakili Jerman, pengenalan perundangan cukai dan ekonomi yang menjamin kepentingan rakyat, dan penghapusan hak istimewa golongan feudal. ${ }^{19}$

Nasib yang sama turut menimpa bahagian utara Jerman, iaitu negeri Prusia. Krisis ekonomi menyebabkan Raja Frederick William IV terpaksa memanggil satu perhimpunan perundangan kebangsaan (United Diet). ${ }^{20}$ Kewangan Prusia mengalami defisit dan Undangundang 1820 mewajibkan supaya sebarang peningkatan cukai ataupun pinjaman baru perlu mendapat kelulusan perwakilan rakyat. Apabila Majlis Perwakilan (daripada jawatankuasa lapan wilayah Prusia) bersidang, wakil-wakil parlimen menolak permintaan William IV untuk kelulusan pinjaman. Sebaliknya, mereka mengharapkan William IV mengotakan janji untuk sebuah perlembagaan perwakilan yang dijanjikan oleh ayah baginda pada 1813 dan 1815. Mereka menuntut pembaharuan politik, perlembagaan bertulis, kebebasan akhbar dan sistem juri dalam perbicaraan. Namun, William IV tidak berminat dalam kerajaan berperlembagaan. Bukan sahaja golongan borjuis yang menyuarakan penentangan terhadap pemerintahan mutlak dan sistem feudal, tetapi kaum petani dan bangsawan turut terlibat. Matlamat Raja Prussia memanggil persidangan itu tidak tercapai malahan baginda menyatukan kuasa-kuasa penentangan. ${ }^{21}$

Pada 1847, William IV sekali lagi memanggil wakil-wakil Parlimen wilayah ke Berlin untuk melaksanakan tanggungjawabnya dalam meluluskan pinjaman dan peningkatan cukai. Harapan golongan liberal hancur apabila Raja Prussia dalam ucapan pembukaan parlimen Prusia pada 11 April 1847, mengisytiharkan bahawa baginda tidak akan meluluskan satu perlembagaan baru seperti dalam kenyataannya iaitu, Never will I permit a written sheet of paper to come between our God in heaven and this land, as if it were a second Providence, to rule us with its paragraphs and supplant the old sacred loyalty. ${ }^{22}$

Pengisytiharan tersebut bererti tuntutan golongan liberal tidak diiktiraf, tuntutan untuk mesyuarat berpenggal parlimen tidak diendahkan, hak parlimen dalam pembentukan undang-undang baru dinafikan dan penjaminan status parlimen dalam satu perlembagaan bertulis ditolak. Kegagalan mendapatkan konsesi daripada raja dan pengalaman dalam kerajaan perwakilan menyebabkan wakil-wakil enggan meluluskan belanjawan. Apabila parlimen Prusia peringkat kebangsaan sekali lagi enggan meluluskan rang undang-undang pinjaman kerajaan, raja Prusia membubarkan persidangan itu pada 26 Jun 1847. Perdebatan antara raja dan kelas pertengahan di istana Berlin 
tamat dan Prusia kembali kepada zaman pemerintahan beraja mutlak. Selepas kegagalan pembaharuan dalam parlimen, isu perlembagaan masih diperdebatkan dalam kalangan rakyat biasa dan mendapat liputan luas akhbar. Peluang untuk kompromi tuntutan perlembagaan lenyap dan revolusi merupakan satu-satunya cara penyelesaian masalah negara. ${ }^{23}$

\section{Revolusi Mac: Realisasi Tuntutan Liberalisme}

Raja Prusia akhirnya bersetuju memberi sedikit konsesi berikutan daripada kejatuhan kerajaan beraja Louis Philippe, di negara jiran Perancis. Berita pengiystiharan Republik Perancis menyebabkan raja Prusia berjanji pada 14 Mac untuk memanggil semula persidangan 'United Diet', yang dibubarkan setahun yang lalu. Pada 18 Mac, William IV mengisytiharkan persetujuan baginda untuk kerajaan perlembagaan dan menjanjikan pembaharuan politik Prussia. Namun kompromi tersebut sudah terlambat. Revolusi telahpun tercetus pada hari yang sama. Perkumpulan damai rakyat di hadapan istana diraja untuk membincangkan Revolusi Februari di Paris tiba-tiba bertukar menjadi revolusi berdarah berikutan serangan tentera ke atas khalayak ramai. Rakyat awam bersemuka dengan tentera diraja dan pelepasan beberapa das tembakan memulakan rusuhan berdarah. Raja Prusia akhirnya tunduk pada kehendak pejuang revolusi dengan mengundurkan angkatan tentera, memberi tabik hormat kepada rakyat yang terkorban, mengampunkan banduan politik, menjanjikan kebebasan politik dan bersumpah untuk merealisasikan penyatuan Jerman. ${ }^{24}$

Revolusi tercetus secara spontan di luar rancangan golongan kelas pertengahan. Dengan erti kata yang lain, suasana ataupun asas revolusi telahpun wujud. Frederick Engels menggambarkan kematangan Jerman untuk revolusi seperti berikut, "Germany was, in the beginning of 1848, on the eve of a revolution, and this revolution was sure to come, even had the French Revolution of Februari not hastened it." 25 Engels percaya revolusi-revolusi 1848 tidak dapat dibendung apabila seluruh lapisan masyarakat mempunyai keinginan pembaharuan dan perubahan sungguhpun keinginan itu tidak sama.

That the sudden movements of February and March 1848, were not the work of single individuals, but spontaneous, irresistable manifestations of national wants and necessities, more or less clearly understood, but very distinctly felt by numerous classes in every country, is a fact recognized everywhere... ${ }^{26}$

Di seluruh Jerman, berita kejatuhan Louis Philippe daripada takhta kerajaannya, menggemparkan raja-raja Jerman yang sekarang 
mencari jalan menenteramkan arus revolusi. Keadaan huru hara seperti pemberontakan petani di luar bandar dan rusuhan artisan di bandar menyebabkan raja-raja cuba berdamai dengan golongan liberal. Apabila rusuhan semakin menular, raja-raja telahpun bertindak melucutkan menteri yang konservatif, mengisytiharkan janji perlembagaan dan menyokong pergerakan liberalisme. Misalnya perletakan jawatan Canselor Austria, Metternich dilihat sebagai percubaan menyelamatkan pentadbiran diraja dan meredakan ketidakpuasan rakyat. ${ }^{27}$

Pada peringkat golongan bawahan, rakyat biasa menyertai revolusi secara spontan dan secara tiba-tiba berminat dengan isu politik. Seluruh strata sosial masyarakat terlibat dalam protes sosial.Protes sosial inilah yang menjadi penggerak sebenar di sebalik revolusi. ${ }^{28}$ Pergerakan bawahan ini diikuti dengan perkembangan idea liberalisme berikutan jaminan kebebasan akhbar. Selaras dengan itu, akhbar-akhbar tempatan telah memberikan liputan yang meluas kepada politik kebangsaan dan juga perkembangan Majlis Perhimpunan Frankfurt. Pendapat umum berkembang dengan pesat di setiap wilayah dan penduduk bandar menunjukkan kematangan politik mereka. Keadaan selepas Revolusi 18 Mac turut menyaksikan pembentukan parti-parti politik buat kali pertama dalam sejarah Jerman. Pertubuhan politik tidaklah terhad kepada parti parlimen ataupun parti kerajaan tetapi merangkumi pelbagai spektrum politik seperti aliran konservatif, liberal, demokrat, agama, dan persatuan pekerja. ${ }^{29}$ Pada peringkat seterusnya, iaitu revolusi pada peringkat badan perwakilan, pilihanraya dijalankan di Frankfurt, Berlin, Vienna, Munich, Stuttgart, Oldenburg, Bremen, Altenburg dan lain-lain. Perlembagaan yang lama dipinda dan elemenelemen demokratik diperkenalkan. ${ }^{30}$

Selepas golongan liberal mengukuhkan kuasa mereka hampir di setiap negeri Jerman, langkah seterusnya ialah menyatukan golongan liberal daripada 36 negeri Jerman untuk membentuk semula pentadbiran Jerman. Hasilnya persidangan awal parlimen (satu mesyuarat tertutup) diadakan pada 31 Mac di Gereja St. Paul, Frankfurt am Main untuk menentukan hala tuju perlembagaan di Jerman. Wakil-wakil parlimen perlu memutuskan sama ada masa depan sistem pemerintahan beraja perlu diteruskan ataupun dikekalkan dalam sistem berperlembagaan. ${ }^{31}$ Apabila rusuhan telah diredakan, parlimen awal ini meneruskan agenda mereka untuk pilihan raya Majlis Kebangsaan. Hak mengundi diberikan kepada semua rakyat Jerman yang bebas yang mencapai umur majoriti. Pada 18 Mac 1949, 330 perwakilan yang dipilih dari seluruh Jerman bersidang di Gereja St. Paul dan bermulalah sesi Parlimen Frankfurt untuk merealisasikan gagasan nasional seperti kebebasan dan perpaduan. ${ }^{32}$ 
Parlimen Frankfurt dipertanggungjawab dengan tugas merangka satu perlembagaan untuk seluruh Jerman. Perbincangan selama enam bulan itu berakhir pada 28 Disember dengan pengisytiharan dokumen Hak Asasi Rakyat Jerman (Fundamentals Rights of the German People). Pencapaian revolusi ini menjadi kebanggaan kerana menjamin hak persamaan di sisi undang-undang, kebebasan bersuara, beragama, dan kebebasan badan kehakiman. Dokumen ini menjamin hak-hak kerakyatan, menghapuskan perhambaaan yang masih kekal dan mengekalkan badan perundangan berperwakilan. Selepas kejayaan pertama ini, Parlimen Frankfurt meneruskan usaha merangka bahagian perlembagaan yang selebihnya. ${ }^{33}$

Satu persoalan penting ialah struktur politik yang patut diguna pakai oleh satu negara bangsa Jerman pada masa depan. Tidak dinafikan bahawa wakil-wakil parlimen mempunyai pertikaian mengenai sistem kerajaan kelak. Namun mereka mencapai kompromi atas sistem persekutuan, (menggantikan sistem Konfederasi Jerman yang wujud sejak 1815), demokrasi dan perlembagaan demi mencapai penyatuan Jerman. ${ }^{34}$

\section{Matlamat Revolusi: Antara Ideal Liberalisasi atau Nasionalisme}

Dua persoalan sering ditimbulkan oleh sejarawan berkaitan dengan matlamat akhir revolusi 1848 ialah liberalisme Jerman atau nasionalisme Jerman. Di Jerman, matlamat liberalisme tidak begitu diterima umum. Sebaliknya persoalan nasionalisme Jerman tidak pernah dipertikaikan dalam sejarah historiografi Jerman. Sejarawan Jerman bersetuju matlamat akhir ialah penyatuan 36 negeri Jerman dalam satu negara bangsa. Parti-parti politik dalam Parlimen Frankfurt mencapai kata sepakat atas objektif pembentukan negara bangsa. ${ }^{35}$ Matlamat nasionalisme Jerman adalah lebih menonjol dalam revolusi 1848 berbanding dengan ideal liberalisme.

Aspirasi penyatuan nasional terbukti apabila perbincangan perlembagaan menekankan idea pan-Jerman. Apabila Parlimen Frankfurt membincangkan hak liberal rakyat Jerman, cita-cita yang ingin dicapai oleh Parlimen Frankfurt jauh melebihi pemberian hak liberal ataupun menggalakkan kerakyatan aktif semata-mata. Wakilwakil parlimen bercita-cita menghapuskan sekatan yang dihadapi oleh rakyat di negeri-negeri Jerman yang lain. Dalam hal ini, mereka ingin meluaskan hak individu seperti hak menetap dan memiliki hartanah ke seluruh empayar Jerman yang bakal ditubuhkan. ${ }^{36}$

Selain itu, Parlimen Frankfurt ingin mewujudkan satu kesetiaan yang menjangkaui kesetiaan kenegerian. Kesetiaan baru ini mestilah diberikan kepada Empayar Jerman dan bukannya negeri individu. 
Perkara yang pasti adalah wakil-wakil rakyat bersetuju dengan asas kesetiaan baru, tidak kira objek kesetiaan asal mereka. ${ }^{37}$ Sungguhpun Parlimen Frankfurt ingin menyatupadukan seluruh Jerman, mereka tidak dapat mencapai kata sepakat mengenai cara pelaksanaannya. Situasi Jerman menunjukkan kekompleksan dalam merealisasikan idea pembentukan satu negara bangsa. Berbanding dengan negara Eropah yang lain, Jerman terdiri daripada pelbagai unit-unit politik yang berdasarkan kesetiaan yang kuat kepada raja. Dua negeri Jerman yang paling berpengaruh, Austria dan Prusia bersama-sama dengan negeri-negeri Jerman lain, membentuk Konfederasi Jerman sejak 1815. Austria bukanlah sebuah negeri Jerman secara ekslusif kerana terdapat banyak wilayah jajahan Austria yang bukan Jerman. ${ }^{38}$

Menurut Hans Rothfels, adalah mengecewakan apabila Parlimen Frankfurt tidak memberikan tumpuan menyelesaikan isu ini tetapi memberikan perhatian untuk merangka satu perlembagaan hak asasi manusia. Perlembagaan ini digambarkan sebagai 'the interior decoration of a house not yet existing.' Segala usaha adalah sia-sia selagi isu utama iaitu struktur negara Jerman tidak dapat diputuskan. Kekurangan ini dilihat oleh Rothfels berpunca daripada keahlian akademik Parlimen Frankfurt yang 'lacking sense of reality.' Parlimen kebangsaan Jerman yang pertama ini digambarkan sebagai 'parlimen profesor' kerana kebanyakan delegasinya adalah golongan berpendidikan tinggi iaitu $3 / 4$ adalah bekas pelajar universiti, termasuk guru besar sekolah dan pensyarah universiti. ${ }^{39}$

Persaingan antara dua kuasa besar Jerman iaitu Austria dan Prusia telah menyulitkan proses penyatuan Jerman. Proses ini bertambah sukar apabila wakil-wakil parlimen terpaksa memilih antara dua kuasa tersebut yang membawa kepada perpecahan pilihan antara penyatuan Jerman kecil (kleindeutsch) dan Jerman besar (grossdeutsch). Penyokong kleindeutsch mencadangkan supaya empayar Jerman baru hanyalah merangkumi Prusia dan negeri-negeri Jerman yang kecil manakala penyokong grossdeutsch dalam Parlimen Frankfurt ingin memasukkan Austria dalam empayar Jerman. Pilihan antara kleindeutsch dan grossdeutsch melibatkan masa depan empayar Habsburg. Apabila undian dilaksanakan pada 1 Oktober 1848 untuk membubarkan Empayar Habsburg dan memasukkan wilayah Austria yang berbangsa Jerman dalam empayar Jerman, delegasi-delegasi Austria dalam parlimen itu tidak dapat mencapai kata sepakat. Delegasi Austria bercanggah pendapat antara setuju, tidak bersetuju dan tidak mengundi langsung. ${ }^{40}$

Mengetahui keadaan menemui jalan buntu, parlimen kemudiannya merangka kompromi baru untuk cadangan grossdeutsch. Di bawah cadangan baru, hanya wilayah-wilayah Jerman di bawah pengaruh Austria yang akan disatukan dengan Jerman manakala wilayah-wilayah 
bukan Jerman tidak akan menjadi sebahagian daripada empayar Jerman tetapi ditadbir sebagai entiti yang berasingan oleh Austria. Cadangan ini ditolak oleh Putera Schwarzenberg apabila beliau menjadi menteri luar Austria yang baru. Sebaliknya Schwarzenberg mengusulkan cadangan kepada Parlimen Frankfurt pada Mac 1849 supaya diwujudkan satu badan perundangan di mana bilangan kerusi perwakilan dikira berdasarkan jumlah populasi penduduk. Jika usul ini diterima, Austria dengan populasinya seramai 38 juta berbanding 70 juta penduduk di seluruh Jerman akan mendominasi parlimen yang baru dan jumlah 38 juta termasuklah rakyat Austria yang bukan berbangsa Jerman. Seperti yang dijangka, usul ini ditolak oleh parlimen yang kemudiannya memutuskan untuk pembentukan empayar Jerman tanpa Austria (kleindeutsche). ${ }^{41}$

Pada 28 Mac 1849, perdebatan berakhir dengan pengumuman satu perlembagaan baru untuk Jerman selepas 10 bulan persidangan Majlis Kebangsaan iaitu Perlembagaan 1849 yang memperuntukkan persamaan hak untuk semua rakyat Jerman. Artikel 137 menjamin "there are no class differences before the law." Sehubungan dengan itu, pangkat bangsawan dihapuskan, semua hak istimewa dihapuskan, semua gelaran kebesaran kecuali yang berkaitan dengan jawatan kerajaan dihapuskan, jawatan awam dibuka kepada semua rakyat kaum lelaki berdasarkan keupayaan dan semua rakyat tertakluk kepada kerahan tentera secara sama rata. ${ }^{42}$ Selaras dengan usaha mewujudkan sebuah negara Jerman yang bersatu, perlembagaan mewujudkan kerakyatan persekutuan yang diberikan kepada setiap orang Jerman. Hak kerakyatan itu boleh dinikmati di setiap negeri Jerman. ${ }^{43}$ Ini bererti sekatan antara negeri dihapuskan dan orang Jerman berhak menetap, memiliki hartanah, bekerja dan memohon kerakyatan negeri di negeri Jerman yang lain. ${ }^{44}$

Kepentingan perlembagaan tidak boleh dipertikaikan. Mereka membentuk kerajaan persekutuan yang kukuh dengan seorang raja berperlembagaan yang kuasanya dihadkan oleh kuasa perundangan. Kuasa membuat undang-undang kekal di bawah bidang kuasa parlimen dengan hak mengundi sejagat diberikan kepada kaum lelaki sahaja. ${ }^{45}$ Untuk menghalang pemeritahan autokratik oleh pihak majoriti dalam Persekutuan Jerman yang baru, pihak parlimen merasakan perlu diwujudkan satu badan eksekutif dan dilantik ketua negara yang kuat dan bebas serta terpisah daripada badan perundangan. Dengan mengambil kira sejarah dan tradisi Jerman, mereka berpendapat seorang monarki adalah calon yang terbaik untuk mengetuai badan eksekutif. Mereka percaya hanya Raja Prusia, Friedrich Wilhelm IV mampu menjalankan tugas ini dan mengatasi persaingan kuasa antara negeri- 
negeri Jerman. Justeru mereka mengundi untuk menawarkan takhta kerajaan kepada baginda. ${ }^{46}$

Namun begitu, mereka tidak menyangka bahawa William IV akan menolak tahkta diraja Jerman. Sungguhpun raja Prusia menolak pengurniaan takhta diraja, Parlimen Frankfurt meluluskan resolusi bahawa perlembagaan diraja adalah undang-undang Jerman dan mesti dilaksanakan. Dengan itu, mereka mencadangkan cara melaksanakan perlembagaan itu. ${ }^{47}$ Dalam keadaan ini, berlaku perbalahan antara Majlis Kebangsaan di Frankfurt dan kerajaan negeri. Parlimen negeri-negeri Prusia, Hanover, Saxony, Baden dan Württemberg mengisytiharkan penerimaan perlembagaan tetapi pengisytiharan berkenaan tidak diiktiraf oleh kerajaan negeri mereka. Parlimen negeri Prusia dibubarkan secara tidak sah. Pada 28 April 1849, kerajaan Prusia mengisytiharkan perlembagaan diraja sebagai satu dokumen berunsur "anarki" dan "revolusioner." Dengan erti kata lain, Prusia menafikan kuasa Parlimen Frankfurt. Tindakan Prusia membubarkan parlimen negeri diikuti oleh kerajaan negeri Hanover dan Saxony atas cadangan Prusia. ${ }^{48}$

\section{Perpecahan Parlimen Frankfurt dan Kegagalan Revolusi}

Konflik perlembagaan menjadi semakin serius apabila kerajaan Austria memanggil kembali wakil mereka di Parlimen Frankfurt. Menyedari keadaan masa itu terdapat delegasi parlimen yang mengundurkan diri. Tanpa mengambil kira keputusan kerajaan negeri, Parlimen Frankfurt mengisytiharkan bahawa Perlembagaan Imperial akan dilaksanakan dengan serta merta dan pilihan raya akan dijalankan untuk memilih wakil dewan rakyat. Engels melihat seruan parlimen Franfurt sebagai jemputan perang terhadap kerajaan negeri yang tidak mengiktiraf perlembagaan tersebut. Prusia dan Bavaria juga mengarahkan pengunduran perwakilan parlimen mereka dan membuat persiapan perang terhadap majlis kebangsaan itu. ${ }^{49}$

Di seluruh negara, demonstrasi besar-besaran diadakan untuk menyokong perlembagaan diraja dan majlis kebangsaan. Gerakan menyokong perlembagaan menunjukkan kecenderungan ke arah kekerasan. Rakyat misalnya mula bertindak memulaukan Raja Frederick Augustus II dari Dresdan, tentera kerajaan di Westphalia mengingkari arahan kerajaan dan mempertahankan perlembagaan, rakyat di Palatinate merampas kuasa kerajaan dan meletakkannya di bawah perlindungan dewan perhimpunan dan rakyat di Württemberg memaksa raja mengiktiraf perlembagaan itu. Keadaan ini seakan-akan menunjukkan rakyat sedang menunggu isyarat daripada Parlimen Frankfurt untuk satu pemberontakan bersenjata. ${ }^{50}$ 
Engels menyalahkan pihak Parlimen Frankfurt kerana gagal memobilisasikan arus demonstrasi pada masa itu untuk mencetuskan satu pemberontakan bersenjata bagi mempertahankan kerajaan berperwakilan dan menentang golongan birokrasi yang anti perlembagaan. Sebaliknya, mereka cuba menenteramkan demonstrasi ataupun membenarkan demonstrasi tersebut dikalahkan tanpa memberi sebarang bantuan ataupun pengiktirafan. Mereka berucap, memprotes, mengusulkan rayuan, dan meluluskan resolusi tetapi tidak mengambil sebarang langkah sedangkan tentera diraja semakin mara. ${ }^{51}$ Pemberontakan bersenjata yang tercetus di negeri-negeri Jerman telah menakutkan golongan liberal yang mulanya bersimpati dengan tuntuan demokratik. Pandangan antirevolusi dan antidemokratik mulai kelihatan dan bertambah kukuh apabila Canselor Prusia, iaitu Bismarck menyakinkan mereka bahawa kerjasama dengan kerajaan merupakan cara terbaik untuk mencapai matlamat mereka. ${ }^{52}$ Menghadapi bahaya ini, kelas pertengahan yang letih dengan revolusi, mendesak parlimen supaya menyelesaikan isu perlembagaan dengan secepat mungkin. ${ }^{53}$

Akhirnya, pada Julai 1849, revolusi berjaya ditamatkan. Kedudukan raja-raja dipulihkan dalam gerakan antirevolusi. Kuasa eksekutif raja telah dikembalikan dengan sokongan bangsawan, askar, dan kakitangan kerajaan serta pasukan polis. Satu siri pemberontakan yang terakhir di Prussia, Saxony, Palatinate dan Baden kesemuanya ini dihapuskan dengan kerjasama ketenteraan sesama raja-raja Jerman. Kerajaan monarki berjaya menutup tirai revolusi dengan bantuan ketenteraan daripada negeri Jerman yang lain. Selepas keamanan dikembalikan, mahkamah perang menjatuhkan hukuman kepada pejuang-pejuang revolusi. ${ }^{54}$

Jikalau revolusi Mac 1848 disokong oleh khalayak ramai, gerakan anti-revolusi pada Mei 1849 oleh golongan monarki hanya dilihat secara pasif sahaja. Petani dan pekerja tidak menunjukan keghairahan untuk mempertahankan ideal perlembagaan lagi. Angkatan tentera diraja terbukti tiada bandingannya dengan angkatan rakyat biasa. Dalam percubaan terakhir golongan kelas pertengahan mempertahankan institusi perlembagaan, misalnya di Palatinate, hanya 8,000 daripada 600,000 penduduk menyokong rayuan demokratik. Di Baden, hanya 40,000 daripada 1.3 juta penduduk berarak mempertahankan perlembagaan Frankfurt. Pada 23 Julai, pejuang revolusi gagal mempertahankan bandar Rastatt dan kejatuhan ini menandakan berakhirnya revolusi. ${ }^{55}$

Golongan moderat dalam Parlimen Frankfurt telah pulang ke negeri masing-masing sementara pejuang radikal beriktibar meneruskan perjuangan di negeri mereka untuk lebih daripada setahun. Wakil parlimen berpindah ke Stuttgart tetapi kerajaan Württemburg menutup 
dewan perhimpunan Stuttgart atas desakan Prusia dan memulaukan saki-baki pejuang revolusi. Mereka kemudiannya meneruskan perjuangan perlembagaan ke Baden tanpa sebarang kejayaan. ${ }^{56}$

\section{Realiti dan Idealisme dalam Revolusi 1848}

Satu perkembangan yang serupa antara revolusi di Jerman dengan revolusi 1848 di negara Eropah lain adalah mereka berjaya dengan mudah pada peringkat awal dan kemudiannya ditewaskan dengan usaha yang sedikit. Personaliti Raja Frederick William IV dikatakan sebagai faktor serta-merta kekalahan revolusi. Frederick William IV digambarkan sebagai "the man of destiny" yang menentukan takdir revolusi. Baginda sebenarnya bersetuju dengan revolusi pada awalnya tetapi menentangnya kemudian dan akhirnya menolak takhta pada 3 April 1849 menyebabkan revolusi itu hanya tinggal sebagai impian. ${ }^{57}$

Bercanggah dengan kesimpulan yang diterima umum, Frank Eyck tidak melihat kegagalan perlembagaan disebabkan peranan Raja Prusia. Sejarawan lain dikatakan menyalahkan Prusia atas kekecewaan revolusi. Sebaliknya, Eyck mempersoalkan sama ada matlamat penyatuan dan perkembangan perlembagaan adalah tugas yang terlalu besar untuk dipikul oleh Parlimen Frankfurt. Mampukah kedua-dua matlamat itu dilakukan pada masa yang sama? Menurut beliau, adalah lebih baik untuk Parlimen Frankfurt memfokuskan satu aspek sahaja. Daripada sudut pandangan perwakilan Parlimen Frankfurt, keduadua aspek merupakan masalah yang sama. Sistem Konfederasi Jerman menurut mereka, menghalang perkembangan politik. Perkembangan perlembagaan hanya dapat dicapai jika Konfederasi Jerman dibubarkan dan negeri Jerman disatukan..$^{58}$

Friedrich Meinecke berpendapat percubaan demokrasi Jerman yang pertama ini jauh melebihi realiti sehingga kekal sebagai satu perjuangan ideologi. Ideal revolusi ini dikalahkan oleh kuasa yang lebih kuat iaitu realiti tentang wujudnya kepentingan pelbagai kelas sosial yang berbeza. ${ }^{59}$ Revolusi di Jerman mengalami masalah yang lebih kompleks daripada revolusi yang serupa di negara lain Eropah. Revolusi sosial yang mengambil bentuk perjuangan kelas di Jerman bercampur aduk dengan revolusi nasional yang pada akhirnya menampakkan kegagalan kedua-duanya. Rakyat melihat revolusi dan ideal demokrasi sebagai penyelesaian penderitaan mereka. Konsep demokrasi turut diguna pakai oleh kelas menengah bersama-sama dengan tuntutan sosialis. Namun, ideal demokrasi pada peringkat ini bertujuan untuk menolak sistem autokratik raja dan bukanlah menandakan semangat kerjasama antara semua kelas. Ketidakpercayaan dan keangkuhan dalam kalangan 
pelbagai kelas terhadap kelas yang lain, telah memisahkan kelas-kelas tersebut dalam matlamat mereka menentang autoriti lama. ${ }^{60}$

Jika pelbagai susun lapis masyarakat tidak berkongsi matlamat yang sama maka tidak akan wujud perpaduan untuk tindakan. Tidak hairanlah jikalau perjuangan-perjuangan yang saling tiada berkaitan ini terbubar dengan sendiri, tanpa mencapai sebarang keputusan. Parlimen Frankfurt tidaklah boleh dikatakan mewakili perpaduan Jerman. Jerman masih terpisah antara tiga kuasa besar yang merdeka iaitu Prusia, Austria dan Konfederasi Jerman dalam 36 negeri Jerman. ${ }^{61}$ Kewujudan pelbagai kelas sebelum tercetusnya revolusi menjelaskan ketidakseragaman dan kontradiksi yang bakal wujud dalam pergerakan itu. Sejak awal lagi, pergerakan ini dilemahkan oleh kepentingan kelas yang berbeza, malahan bercanggah. Tidak terdapat satu pusat kawalan di Jerman yang mampu membuat keputusan untuk mengkordinasikan gerakan revolusi di negeri-negeri Jerman. ${ }^{62}$

Mereka yang memimpin perjuangan pada kesemua peringkat revolusi gagal memahami kedinamikan keseluruhan revolusi dan tidak mempunyai satu matlamat umum yang dipersetujui. Pembentukan satu perlembagaan untuk seluruh empayar Jerman adalah satu matlamat, tetapi tujuan revolusi adalah lebih daripada itu. Perbincangan di atas menunjukkan revolusi merupakan satu penyelesaian untuk memperbaik keadaan sosioekonomi. Revolusi dilihat sebagai cara penyelesaian kepada masalah pertambahan penduduk, kebuluran, inflasi, pengganguran, dan eksplotasi pekerja kilang. Pada masa yang sama, revolusi dilihat sebagai emansipasi politik yang berteraskan parti politik, kebebasan akhbar, parlimen, persatuan politik dan penglibatan rakyat. Oleh itu, Seimann menyimpulkan "no single simple interpretation of the 1848-49 revolutions in Germany can be offered." 63

Sejarawan cuba menjelaskan sebab kegagalan gerakan nasionalisme Jerman berdasarkan kekuatan sistem monarki. Institusi birokratik diraja terbukti lebih kukuh daripada yang difikirkan. Perasaan kesetiaan rakyat kepada negeri beraja mereka dan juga perasaan egoistik rajaraja bertentangan dengan seruan penyatuan Jerman yang membawa bersamanya perasaan kesetiaan kepada negara bangsa yang baru. Kumpulan yang bersedia mengidenfikasikan diri dengan kesetiaan baru dan bertindak menentang perpecahan dalam Jerman pula tidak dapat bersatu atas prioriti matlamat perjuangan. ${ }^{64}$ Jerman terdiri daripada pelbagai unit-unit politik yang berdasarkan kesetiaan yang kuat kepada raja dan sistem dinasti. Kewujudan kepelbagaian unit politik telahpun menyulitkan sebarang usaha penyatuan sejak awal lagi. ${ }^{65}$

Jika revolusi Jerman berjaya, ia akan membawa Jerman ke arah proses pembaratan dan pendemokrasian untuk masa depan yang lebih cerah. Adalah tidak memadai untuk menjelaskan kegagalan 
revolusi dengan faktor keadaan sosial semasa dan situasi antarabangsa yang tidak cukup matang. Rothfels mengemukakan hujah bahawa kegagalan itu berakar umbikan masalah sejarah Jerman itu sendiri. Terdapatnya kekurangan pada perkembangan negara bangsa Jerman yang menyebabkan Jerman tidak boleh melancarkan satu revolusi yang berjaya. Dengan erti kata lain, Jerman tidak sesuai untuk idea revolusi. ${ }^{66}$

Tambahan pula, masyarakat Jerman dianggap tidak bersedia menerima ideal liberalisme. Sungguhpun revolusi 1848 menonjolkan kesedaran rakyat dalam hal politik untuk kali pertama dalam sejarah, terdapat persoalan sama ada rakyat cukup matang untuk pengamalan demokrasi atau idea liberal yang diperjuangkan oleh Parlimen Frankfurt sesuatu yang praktikal ataupun ideal semata-mata tanpa "real politic." ${ }^{67}$ James H. Harris nampaknya bersependapat dengan Gordon Craig bahawa "cita-cita liberalisme yang diperjuangkan oleh sekumpulan rakyat yang berpendidikan telah disekat oleh kemunduran politik rakyat Jerman, ketaatsetiaan mereka yang berlebihan kepada autoriti beraja, amalan kepatuhan yang mendalam dan kesangsian bahawa kerajaan perwakilan adalah sesuatu yang bukan Jerman." 68

Nyatanya liberalisme tidak dapat merealisasikan kepentingan artisan, pekedai, pemilik kilang, ahli perbankan, petani, pemilik tanah dan pekerja kilang. Mereka bersedia menerima kepimpinan ahli parlimen yang liberal dan kesetiaan mereka pada sistem perlembagaan bergantung sama ada sistem itu mampu memuaskan keperluan material mereka. Mereka dapat berjuang atas nama rakyat Jerman kerana mereka menghadapi pengalaman masa lampau yang sama tetapi mereka tidak bersatu dalam membentuk satu masa depan baru. ${ }^{69}$ Hamerow mengingatkan kita bahawa:

The truth is that there was no German Revolution of 1848. There were rather several simultaneous German revolutions, each with its own ideology and objective, all combining their efforts to achieve the overthrow of an oppresive system of government. ${ }^{70}$

Pada umumnya, pengkaji peristiwa 1848 mencapai persepakatan bahawa revolusi itu tidak gagal sepenuhnya. Pencapaian yang boleh dibanggakan termasuklah Parlimen Frankfurt, hak asasi rakyat Jerman, Perlembagaan 28 Mac 1849, peningkatan penglibatan politik rakyat, dan peningkatan semangat perpaduan kebangsaan. ${ }^{71}$ Perasaan nasionalisme dalam kalangan rakyat tidaklah terhapus selepas revolusi itu. Seruan nasionalisme ini berjaya direalisasikan selepas 20 tahun lebih apabila Bismarck menyatukan empayar Jerman. Parlimen Frankfurt menghasilkan produk dokumen perlembagaan walaupun ia tidak dapat dilaksanakan pada 1840-an. Prinsip-prinsip liberalisme 
yang didokumenkan dalam perlembagaan 1849 telah diaplikasikan pada perlembagaan Konfederasi Jerman Utara (1867) dan Empayar Jerman (1871). Idea liberal itu diaplikasikan dengan lebih banyak pada perlembagaan republik Weimar (1819) dan pada perlembagaan Jerman Barat (1849). ${ }^{72}$ Perlembagaan Reich merupakan lambang Revolusi Jerman. Ia adalah "cetak biru" untuk pembentukan suatu negara bangsa Jerman yang merangkumi konsep "kebebasan" (Freiheit) dan "perpaduan" (Einheit). ${ }^{73}$

\section{Kesimpulan}

Suasana politik didominasikan oleh kelas borjuis dan kejayaan mereka dimungkinkan oleh pemberontakan petani dan rusuhan artisan. Dalam jangka masa sebelum tercetusnya revolusi, golongan bawahan menunjukkan peningkatan kesedaran politik yang tinggi. Penglibatan aktif golongan bawahan dalam perjuangan revolusi boleh dijelaskan dengan ketidakpuasan mereka terhadap kedudukan sosioekonomi yang disebabkan oleh kombinasi pelbagai faktor. Ketidakpuasan ini seterusnya menginspirasikan para petani untuk mengidentifikasikan diri mereka dengan idea liberal dan demokratik. Mereka bukanlah pejuang radikal atau revolusi 1848 dan tidak boleh dikatakan sebagai gerakan radikalisme. Seperti yang dibincangkan, revolusi 1848 bukanlah bertujuan menggulingkan sistem politik dan sosial yang sedia ada tetapi bermatlamat pembaharuan. Revolusi 1848 adalah satu gerakan moderat yang menuntut pembaharuan moderat dengan mengekalkan sistem yang sedia ada iaitu sistem beraja.

Hujah Stadelmann bahawa revolusi berakar umbi fahaman ideologi tidak boleh diaplikasikan dalam kes Jerman. Golongan bawahan mengindenfikasikan diri mereka dengan ideal demokrasi untuk memperbaiki status sosial mereka berbanding dengan matlamat mencapai pembaharuan politik. Laungan demokratik hanyalah digunakan sebagai kesempatan untuk mencapai peningkatan status. Sebelum tuntutan perlembagaan bermula, golongan bawahan telahpun terlibat dalam rusuhan kebuluran dan rusuhan kerja. Sepertimana yang dicadangkan oleh Siemann, kombinasi faktor ketidakpuasan menyebabkan rakyat bersatu secara mudah. Mereka percaya segala penyakit sosial itu dapat dipulihkan dengan pembaharuan asas, institusi moden dan sistem politik baru. Tidak hairanlah sekiranya semakin banyak golongan kelas bawahan menjadi penyokong aktif revolusi.

Namun begitu, sokongan golongan ini tidaklah menyeluruh. Mereka bersedia memberikan sokongan aktif pada peringkat awal revolusi tetapi tidak menyokongnya apabila monarki melancarkan gerakan anti-revolusi. Sekiranya revolusi mencapai momentum pada 
peringkat awal revolusi dengan sokongan padu golongan bawahan, revolusi yang sama gagal mencapai kemenangan tanpa sokongan menyeluruh golongan itu. Ketidaksanggupan majoriti mereka mempertahankan perjuangan liberalisme menjelaskan ketewasan pramatang revolusi dengan mudahnya dalam tangan tentera monarki. Oleh itu, revolusi 1848 adalah revolusi kelas bawahan yang dimulakan oleh kelas bawahan dan ditamatkan kerana kelas bawahan gagal mempertahankan arus perubahan dan wajarlah sekiranya Presiden Woodrow Wilson berhujah "The seed of revolution is repression."

\section{Nota}

1 Wolfram Siemann, "The Revolutions of 1848-1849 and the Resistence of the Old Regime in Germany (1848-1850)," in Nineteenth-Century Germany: Politics, Culture and Society, 1780-1918, ed. John Breuilly, London: Arnold, 2001, hlm. 118-20. Donald J. Mattheisen, "History as Current Events: Recent Works on the German Revolution of 1848," American Historical Review 88, no. 5 (1983), hlm. 1221 Ibid., hlm. 1221.

$4 \quad$ Rudolph Stadelmann, Social and Political History of the German 1848 Revolution, trans. James G. Chastain Athens: Ohio University Press, 1975, hlm. 3-5.

$5 \quad$ Ibid., hlm. 6-7.

6 Theodore S. Hamerow, "History and the German Revolution of 1848," The American Historical Review 60, no. 1 (1954), hlm. 43.

$7 \quad$ Han Rothfels, "1848 - One Hundred Years After," The Journal of Modern History 20, no. 4 (1948), hlm. 304.

8 Wolfram Siemann, "The Revolutions of 1848-1849 and the Resistence of the Old Regime in Germany (1848-1850)," hlm. 121-123. Alvin W. Gouldner, "Artisans and Intellectuals in the German Revolution of 1848," Theory and Society 12, no. 4 (1983), hlm. 522-24. Ibid., hlm. 528-529.

Ibid., hlm. 525-26. Friedrich Meinecke, "The Year 1848 in German History: Reflections on a Centenary," The Reviews of Politics 10, no. 4 (1948), hlm. 483. Christopher Clark, "Germany 1815-1848: Restoration or Pre-March?," in Nineteenth-Century Germany: Politics, Culture and Society, 1780-1918, ed. John Breuilly, London: Arnold, 2001, hlm. 56-57. Ibid., hlm. 58-59. Politics in Germany, 1815-1871, Princeton: Princeton University Press, 1958, hlm. 84-86. Ibid., hlm. 78-81. Ibid., hlm. 75.

$18 \quad$ Ibid., hlm. 101-102. 
Ibid., hlm. 88 .

Ibid., hlm. 90.

Frederick Engels, Revolution and Counter-Revolution in Germany, Peking: Foreign Language Press, 1977, hlm. 21-23.

Theodore S. Hamerow, Restoration, Revolution, Reaction: Economics and Politics in Germany, 1815-1871, hlm. 91.

Ibid., hlm. 92-93.

Ibid., hlm. 98-100.

Frederick Engels, Revolution and Counter-Revolution in Germany, hlm.27. Ibid.hlm., 4.

Theodore S.Hamerow, Restoration, Revolution, Reaction: Economics and Politics in Germany, 1815-1871, 98-100.

Wolfram Siemann, "The revolutions of 1848-1849 and the Resistence of the old regime in Germany (1848-1850),"hlm. 120.

Ibid., hlm. 124-126.

Ibid., hlm. 127-129.

Theodore S.Hamerow, Restoration, Revolution, Reaction: Economics and Politics in Germany, 1815-1871, hlm. 118.

Ibid., hlm. 120-21.

Ibid., hlm. 128-29.

Mark Hewitson, "“The Old Forms are Breaking Up, ... Our New Germany is Rebuilding Itself': Constitutionalism, Nationalism and the Creation of a German Polity during the Revolutions of 1848-49," English Historical Review 125, no. 516 (2010), hlm. 1213.

Theodore S. Hamerow, "History and the German Revolution of 1848," hlm. 40.

Ibid., hlm. 1178.

Ibid., hlm. 1212.

Han Rothfels, “1848 - One Hundred Years After," hlm.308.

Ibid., hlm. 310.

Lawrence Sondhaus, "Schwarzenberg, Austria, and the German Question, 1848-1851," The International History Review 13, no. 1 (1991), hlm. 1. Ibid., hlm. 2.

Artikel 137, Perlembagaan Jerman 1849 dalam Elmar M. Hucko, The Democratic Tradition: Four German Constitutions, New York: Berg, 1987, hlm. 106.

Artikel 123, dalam ibid.

Artikel 133 dalam ibid., hlm. 106.

Theodore S. Hamerow, Restoration, Revolution, Reaction: Economics and Politics in Germany, 1815-1871, 130 \& 136.

Mark Hewitson, "'The Old Forms are Breaking Up, ... Our New Germany is Rebuilding Itself': Constitutionalism, Nationalism and the Creation of a German Polity during the Revolutions of 1848-49," hlm. 1213-1214. Frederick Engels, Revolution and Counter-Revolution in Germany, hlm. 12021.

Ibid., hlm. 122-23.

Ibid., hlm. 125-27. 
Ibid.

Ibid., hlm.129-30.

Mattheisen, "History as Current Events: Recent Works on the German Revolution of 1848," hlm.1225.

Engels, Revolution and Counter-Revolution in Germany, hlm. 120-21.

Wolfram Siemann, "The Revolutions of 1848-1849 and the Resistence of the Old Regime in Germany (1848-1850)," hlm.132-33.

Theodore S.Hamerow, Restoration, Revolution, Reaction: Economics and Politics in Germany, 1815-1871, hlm. 193-94.

Frederick Engels, Revolution and Counter-Revolution in Germany, hlm. 14142.

Friedrich Meinecke, "The Year 1848 in German History: Reflections on a Centenary," hlm. 480.

Frank Eyck, The Frankfurt Parliament 1848-1849, London: MacMillan, 1968, hlm.393.

Friedrich Meinecke, "The Year 1848 in German History: Reflections on a Centenary," hlm. 479.

Ibid., hlm. 484.

Engels, Revolution and Counter-Revolution in Germany, hlm. 41.

Ibid., hlm. 13.

Wolfram Siemann, "The Revolutions of 1848-1849 and the Resistence of the Old Regime in Germany (1848-1850)," hlm. 135.

Friedrich Meinecke, "The Year 1848 in German History: Reflections on a Centenary," hlm.481-82.

Han Rothfels, "1848 - One Hundred Years After," hlm. 308.

Ibid., hlm.305.

Wolfram Siemann, "The Revolutions of 1848-1849 and the Resistence of the Old Regime in Germany (1848-1850)," 118.

James F. Harris, "Rethinking the Categories of the German Revolution of 1848: The Emergence of Popular Conservatism in Bavaria," Central European History 25, no. 2 (1992), hlm. 125.

Theodore S. Hamerow, Restoration, Revolution, Reaction: Economics and Politics in Germany, 1815-1871, hlm. 261.

Ibid., hlm. 260.

Wolfram Siemann, "The Revolutions of 1848-1849 and the Resistence of the Old Regime in Germany (1848-1850)," hlm. 136.

Han Rothfels, "1848 - One Hundred Years After," hlm. 311.

Mark Hewitson, "“The Old Forms are Breaking Up, ... Our New Germany is Rebuilding Itself': Constitutionalism, Nationalism and the Creation of a German Polity during the Revolutions of 1848-49," hlm. 1174. 